\title{
Zinc Finger Protein SNAI2
}

National Cancer Institute

\section{Source}

National Cancer Institute. Zinc Finger Protein SNAI2. NCI Thesaurus. Code C50880.

Zinc finger protein SNAI2 (268 aa, $30 \mathrm{kDa}$ ) is encoded by the human SNAI2 gene. This embryonic transcription factor functions as a transcriptional repressor. The protein has been implicated in the metastasis of several cancers. 